\title{
Glass fiber and silica reinforced rigid polyurethane foams
}

\author{
M. W. Kim ${ }^{1}$ S. H. Kwon ${ }^{2}$, H. Park ${ }^{3}$, B. K. Kim ${ }^{1 *}$ \\ ${ }^{1}$ Department of Polymer Science and Engineering, Pusan National University, 609-735 Busan, Korea \\ ${ }^{2}$ Department of Naval Architecture and Ocean Engineering, Pusan National University, 609-735 Busan, Korea \\ ${ }^{3}$ Global Core Research Center for Ships and Offshore Plants, Pusan National University, 609-735 Busan, Korea
}

Received 26 october 2016; accepted in revised form 9 January 2017

\begin{abstract}
Ternary composites of rigid polyurethane foam (RPUF)/glass fiber/silica as well as RPUF/glass fiber have been fabricated from glass fiber, silica, polymeric 4,4'-di-phenylmethane diisocyanate (PMDI) and polyol using HFC 365mfc as blowing agent. Foam formation kinetics, morphology, thermal conductivity, glass transition temperature, decomposition temperatures as well as the mechanical strengths of the foam have been studied. With the addition an increasing amount of glass fiber cream time, rise time, gel time, tack free time, density, compression strength, thermal conductivity $(k)$ monotonically increased while the glass transition temperature showed a maximum at $2 \%$. At constant glass fiber content ( $2 \%)$, addition of silica further increased the process times, density and compression strength while the $T_{\mathrm{g}}$ and thermal decomposition temperature showed a maximum at 3\% silica. The $\mathrm{k}$ value of RFUF/glass fiber composite decreased with the addition of silica up to 3\%, where it was even lower than the virgin RPUF. However, beyond the content k value increased. Overall, the variation of $k$ value with silica content showed identical tendency with cells size and closed cells content.
\end{abstract}

Keywords: polymer composites, polyurethane rigid foams, functionalized silica, physical properties, thermal properties

\section{Introduction}

Polyurethanes (PU) are typically formed by polyaddition reactions of isocyanates with polyols. Depending on the formulation, a broad property spectrum from elastomer to rigid foams are easily designed and synthesized [1-3]. Consequently a myriad of products such as foams, coatings, adhesives, sealants, elastomers, and thermoplastics are obtained and applied in the area of apparels, furnishings, automotive, building, electronics, marine, medical and others with an annual production over 18 million tons 2015 [4-6]. Among the PU products, rigid polyurethane foams (RPUFs) are excellent thermal insulating materials which are widely applied in refrigerators, freezers, hot water tank, liquid natural gas (LNG) cargo, sandwich and roofing panels, and various spray-in-place foams for insulation and sealing in complex cavities [7-9]. The essential feature of RPUF is that the cells are closed and blowing agents are entrapped within the cells [1]. This requires the use of multifunctional (2.5-3.2) polymeric MDI rather than MDI which is strictly di-functional. Consequently networks are formed in the RPUF.

The blowing agents should dissolve well in the reaction mix and remain in the closed cells as a gas which provides the foams with low thermal conductivity without plasticizing cell walls. In addition, they should also be toxicologically and ecologically safe to reduce ozone depletion potentials (ODP) and/or global warming potential (GWP) [10]. Nowadays hydrocarbons (pentane), hydrogen chlorofluorocarbons (H-CFCs) and hydrogenfluorocarbons (H-FCs) are used $[1,4]$.

RPUFs have been reinforced with various types of fillers such as glass fiber $[11,12]$, carbon nanotube (CNT) [13], nanoclay [14, 15], and silica [16] and

$\overline{{ }^{*} \text { Corresponding author, e-mail: bkkim@pnu.edu }}$

(C) BME-PT 
the effects were analyzed in terms of cell forming kinetics, mechanical and thermal properties. It was found that glass fiber and CNT augment mechanical strength but reduce thermal insulation due to the high thermal conductivity of the fillers. Chemical hybridization of silica prevents particle aggregations up to $2 \%$, suggesting enhanced thermal resistance [16]. It is therefore expected that a combination of glass fiber and silica would augment mechanical strength while keeping the thermal resistance at the level of unfilled foam. In this regard, for the first time in the open literature, we synthesized RPUF/glass fiber/silica ternary composite foams where isocyanate groups were introduced into the fumed silica to chemically incorporate it into RPUF. The ternary foam composites were synthesized with varying compositions of glass fiber and silica where polymeric MDI and polyol were used as resin component. A zero ODP blowing agent, viz., $\mathrm{HFC} 365 \mathrm{mfc}\left(\mathrm{CF}_{3} \mathrm{CH}_{2} \mathrm{CF}_{2} \mathrm{CH}_{3}\right)$ was used. The effects of glass fiber in the form of mat [17] and chemically hybridized silica on the performance of RPUF have been studied.

\section{Materials and methods}

\subsection{Raw materials}

Two types of propylene glycol based polyol, i.e., HR-450P (hydroxyl value $=450$, equivalent weight $=$ 124.65) and HD-401 (hydroxyl value $=400$, equivalent weight $=140.26$ ) were supplied by KPX, Korea. High functional polymeric 4, 4'-di-phenylmethane diisocyanate (PMDI) having functionality of 2.7 was provided by Kumho Mitsui Chemicals (Korea). HFC $365 \mathrm{mfc}$ (Solvay Chemicals, Belgium) which is liquid at normal pressure and dissolves adequately in the reaction mix was used as ecofriendly foaming agent. Hexamethylene diisocyanate (HDI) (SigmaAldrich), PC 8 (Air Products) and silicone used as blowing catalyst and surfactant were used as received. Polyols were dehydrated before use at $90{ }^{\circ} \mathrm{C}$ for $24 \mathrm{~h}$ in a vacuum oven. Glass fibers having average diameter of $15 \mu \mathrm{m}$ were incorporated in the form of woven mat purchased from Vetrotex (France). Nano-sized hydrophilic silica (Aerosil 200) with average particle size of $12 \mathrm{~nm}$ was obtained from Evonik (Parsippany, NJ).

\subsection{Isocyanate modification of silica particles}

Silica particles dispersed in dimethyl formamide (DMF) ( $20 \mathrm{mg}$ silica particles/mL DMF) were mixed and reacted with HDI for $24 \mathrm{~h}$ at room temperature to obtain the isocyanate-modified silica particles [16]. Then, the sample was filtered on a glass filter and washed three times with an access amount of acetone. The modification was confirmed by Fourier transform infrared (FTIR) measurements.

\subsection{Syntheses of foams}

The overall reaction scheme to synthesis the composite is shown in Figure 1. The foams were synthesized by one shot method at room temperature [18, 19]. Silica particles carrying isocyanate (NCO) group were reacted with the polyol at room temperature for $6 \mathrm{~h}$ in a four-necked separable flask equipped with a
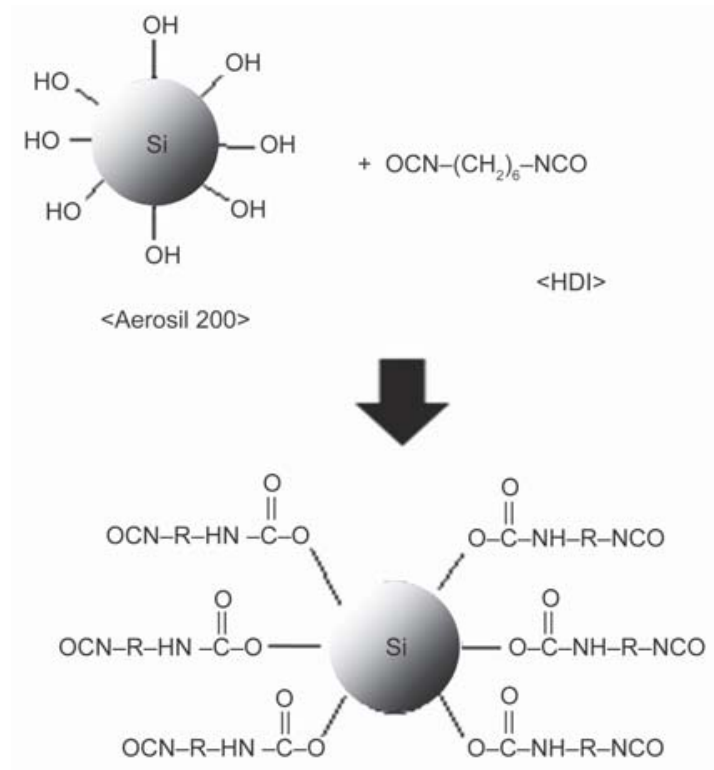

$<$ NCO modified aerosol 200>

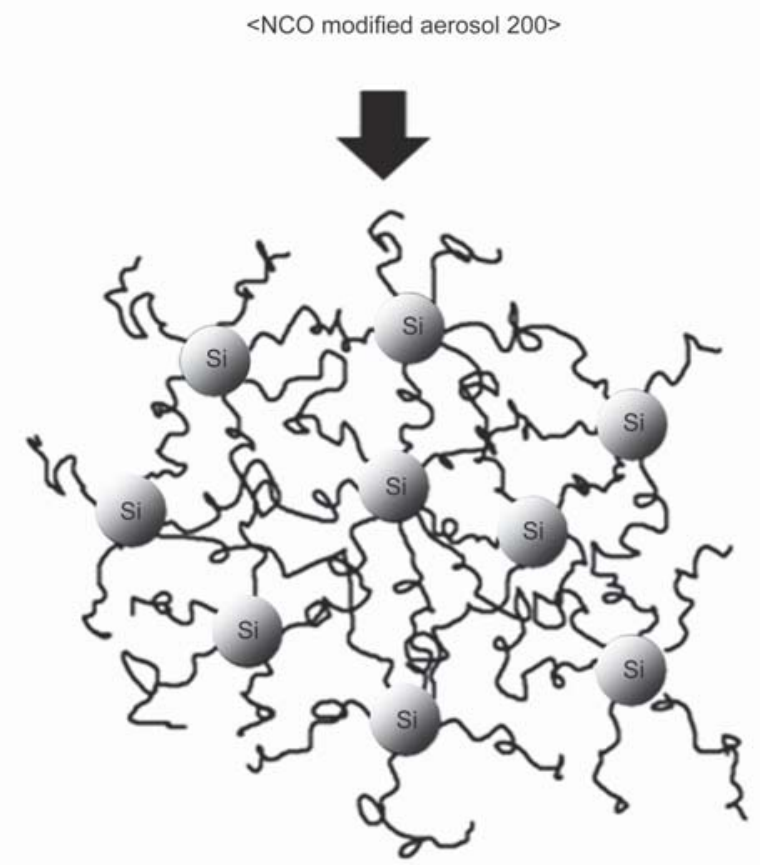

Figure 1. Isocyanate modification of silica particles 
Table 1. Formulation to synthesize the RPUF/Glass mat binary composites (unit: pphp)

\begin{tabular}{|c|c|c|c|c|c|c|c|}
\hline & HR-450P & HD-401 & HFC-365mfc & В 8409 & PC 8 & PMDI & $\begin{array}{c}\text { Glass mat } \\
{[w t \%]}\end{array}$ \\
\hline G0 & \multirow{6}{*}{80} & \multirow{6}{*}{20} & \multirow{6}{*}{12} & \multirow{6}{*}{2} & \multirow{6}{*}{0.6} & \multirow{6}{*}{116.5} & - \\
\hline G1 & & & & & & & 1 \\
\hline G2 & & & & & & & 2 \\
\hline G3 & & & & & & & 3 \\
\hline G4 & & & & & & & 4 \\
\hline G5 & & & & & & & 5 \\
\hline
\end{tabular}

pphp: part per hundred polyol

Table 2. Formulation to synthesize the RPUF/Glass mat/Silica ternary composites (unit: pphp)

\begin{tabular}{|c|c|c|c|c|c|c|c|c|}
\hline & HR-450P & HD-401 & HFC-365mfc & В 8409 & PC 8 & PMDI & $\begin{array}{c}\text { Glass mat } \\
{[w \mathrm{wt} \%]}\end{array}$ & $\begin{array}{c}\text { Silica } \\
{[\mathrm{wt} \%]}\end{array}$ \\
\hline G2 & \multirow{6}{*}{80} & \multirow{6}{*}{20} & \multirow{6}{*}{12} & \multirow{6}{*}{2} & \multirow{6}{*}{0.6} & \multirow{6}{*}{116.5} & \multirow{6}{*}{2} & - \\
\hline GS1 & & & & & & & & 1 \\
\hline GS2 & & & & & & & & 2 \\
\hline GS3 & & & & & & & & 3 \\
\hline GS4 & & & & & & & & 4 \\
\hline GS5 & & & & & & & & 5 \\
\hline
\end{tabular}

pphp: part per hundred polyol

mechanical stirrer to obtain polyol/silica chemical hybrids. This and all other ingredients were put into a mixing cup and mixed thoroughly at $3000 \mathrm{rpm}$ until they become homogeneous. The NCO index (isocyanate equivalents/polyol equivalents) was fixed at 1.10. Glass fiber mat was placed in a rectangular open aluminum mold. Then, the mixtures were poured into the open mold $(270 \times 270 \times 100 \mathrm{~mm})$ and cured for 1 week at room temperature. The formulations to prepare the foams are given in Table 1 and Table 2.

\subsection{Characterizations}

The isocyanate-modified silica particles were confirmed by a Fourier transform infrared (FTIR) spectroscopy. Powders of the sample were uniformly mixed with $\mathrm{KBr}$ by grinding it in an agate mortar. Then, the mixed powders were pressed to a flake using a tablet machine for the FTIR instrument.

The reaction time was measured by a digital stop watch. The closed cell content was determined by an air pycnometer following ASTM D 2856. Foam density was measured with $30 \times 30 \times 30 \mathrm{~mm}$ (width $\times$ length $\times$ thickness) sample following the corresponding ASTM D 1622. Five measurements were made to average. Thermal conductivity was measured using HC-074 (Laser Comp) according to the ASTM C 177.

Scanning electron microscopy (SEM, HITACHI $\mathrm{S} 3500 \mathrm{~N}$ ) was employed to study the cell morphology. Samples were cryogenically fractured in liquid nitrogen and gold sputtered before they were scanned in the free rising direction.

Thermogravimetric analysis (TGA) has been done using TGA Q50 (TA instruments). An 82-10 mg of sample was put in an alumina crucible and heated at $10^{\circ} \mathrm{C} / \mathrm{min}$ under $\mathrm{N}_{2}$ atmosphere, where the flow rate of $\mathrm{N}_{2}$ was $60-40 \mathrm{~L} / \mathrm{min}$. Thermal properties were measured using a differential scanning calorimeter (DSC, Du Pont 9900). Samples were sealed in DSC pan using a crimping and welding press (Du Pont). The DSC thermograms were taken from 60 to $250^{\circ} \mathrm{C}$ at a heating rate of $20^{\circ} \mathrm{C} / \mathrm{min}$. Mechanical properties were measured using a Universal Testing Machine (Ametek, Lloyd) at room temperature. Compression strength was determined according to ASTM D 1621 at a crosshead speed of $3.00 \mathrm{~mm} / \mathrm{min}$ with the sample dimension of $30 \times 30 \times 30 \mathrm{~mm}$ (width $\times$ length $\times$ thickness).

\section{Results and discussion}

\subsection{FT-IR spectra analysis}

As compared with the pristine Aerosil 200 (Figure 2a), the isocyanate-modified silica (Figure 2b) exhibits four additional absorption bands at 1575, 1625, 2270 , and $3450 \mathrm{~cm}^{-1}$. The peaks at 1575,2270 , and $1625 \mathrm{~cm}^{-1}$, respectively, correspond to the $\mathrm{N}-\mathrm{H}$ bending, isocyanate stretching, and $\mathrm{C}=\mathrm{O}$ stretching, indicative of the existence of urethane groups. And the broad band at $3450 \mathrm{~cm}^{-1}$ is identified as N-H stretching mode in urethane groups. 

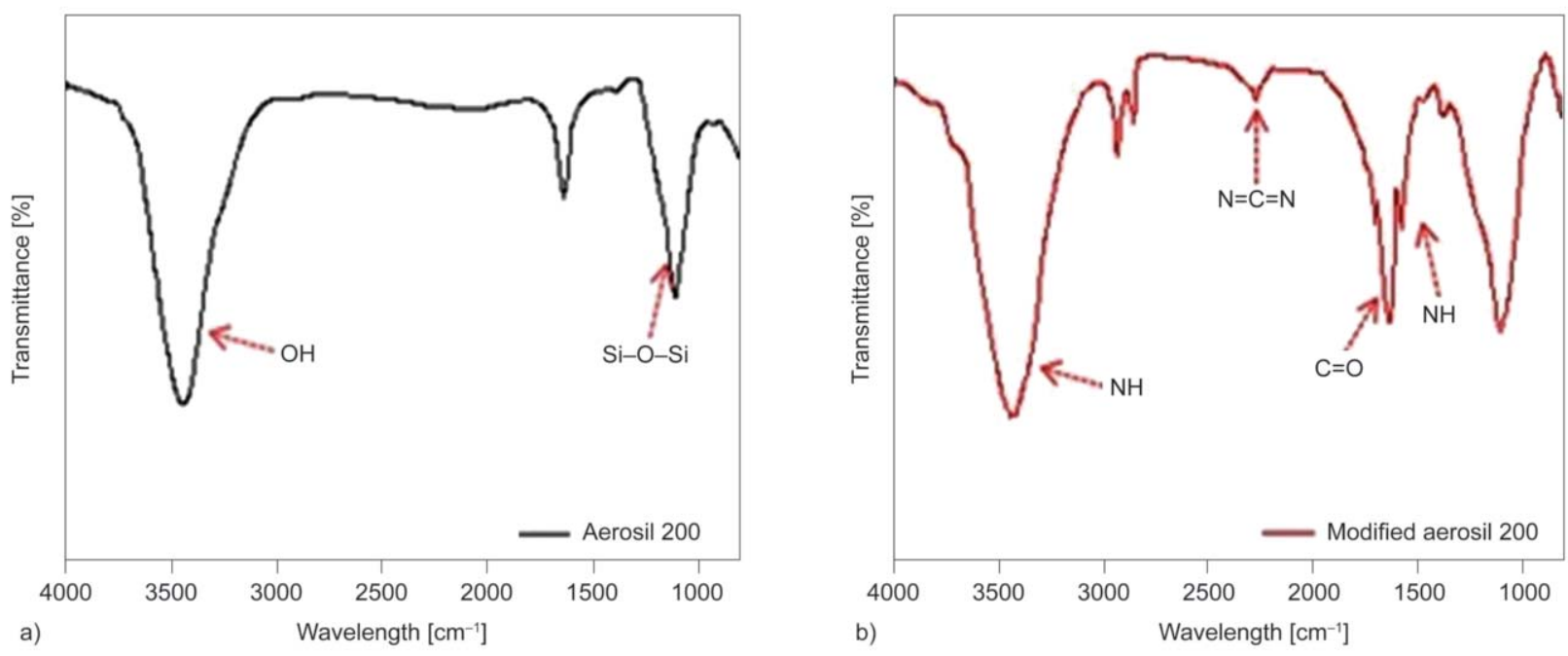

Figure 2. FTIR spectra of (a) pristine silica and (b) isocyanate-modified one

\subsection{Kinetics of foam formation}

The foaming kinetics is generally followed by change of physical appearance such as cream time, rise time, gel time, and tack-free time [1,20]. Exothermic heat of reactions evaporates blowing agents to form bubbles of various sizes which cause light scattering and color of reaction mixture becomes cream-like from dark brown. The time is called cream time. Gel time implies stable network formation by intensive allophanate cross-links [20]. As foam rises, the outer surface loses its stickiness and the foam can be removed from the mold at the tack-free time. It is seen that the cream time is essentially identically for all formulations while rise time, gel time, and tack free time monotonically increase with the addition and increasing glass mat content (Table 3 ). With the addition of glass mat, mixture viscosity increases and the rate of urethane forming reaction and hence rate of foaming reaction decreases.

\subsection{Density}

Densities of the RPUF/glass mat binary composites smoothly increase with the addition and increasing amount of glass mat due mainly to the larger density of glass mat than the urethane foam (Table 3 and

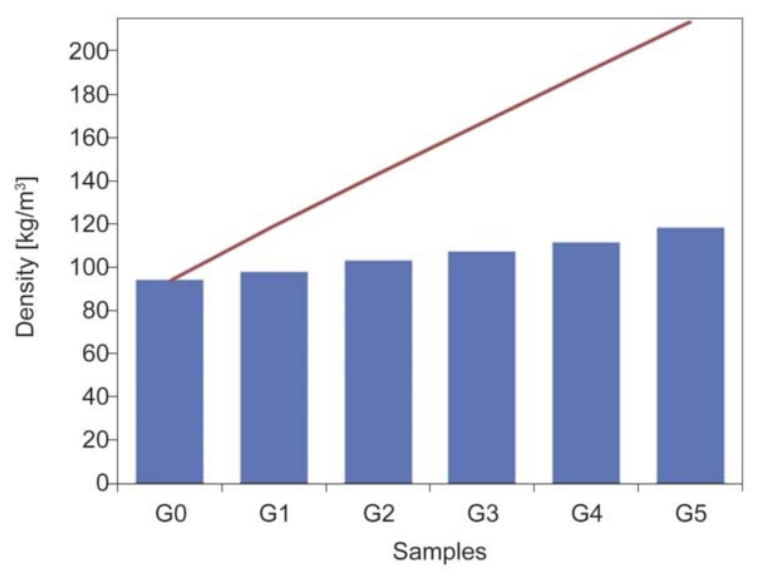

Figure 3. Density of the binary composites vs glass mat content

Figure 3). When the composite density was plotted against the composite composition, a negative deviation from the simple additive rule (line drawn in the figure) was noted, implying the existence of voids between the matrix and glass fibers [21].

\subsection{Thermal properties}

Figure 4 shows the DSC thermograms of the composites, where the $T_{\mathrm{g}}$ of the foam increases with the addition of glass mat showing a maximum at $2 \%$

Table 3. Reactivity and property of the binary composites vs glass mat content

\begin{tabular}{|l|c|c|c|c|c|c|}
\hline & G0 & G1 & G2 & G3 & G4 & G5 \\
\hline Cream time $[\mathrm{s}]$ & $30-35$ & $30-35$ & $30-35$ & $30-35$ & $30-35$ & $30-35$ \\
\hline Rise time $[\mathrm{s}]$ & $220-235$ & $225-240$ & $230-245$ & $235-25$ & $245-260$ & $250-260$ \\
\hline Gel time $[\mathrm{s}]$ & $450-475$ & $465-490$ & $480-505$ & $500-525$ & $520-545$ & $530-550$ \\
\hline Tack-free time $[\mathrm{s}]$ & $740-775$ & $765-800$ & $785-820$ & $810-845$ & $835-870$ & $860-890$ \\
\hline Density $\left[\mathrm{kg} / \mathrm{m}^{3}\right]$ & 93.95 & 97.78 & 102.96 & 107.28 & 111.23 & 118.02 \\
\hline Simple additivity $\left[\mathrm{kg} / \mathrm{m}^{3}\right]$ & 93.95 & 118.15 & 143.07 & 166.91 & 190.30 & 213.33 \\
\hline Compression strength $[\mathrm{MPa}]$ & 0.45 & 0.47 & 0.52 & 0.54 & 0.57 & 0.63 \\
\hline
\end{tabular}




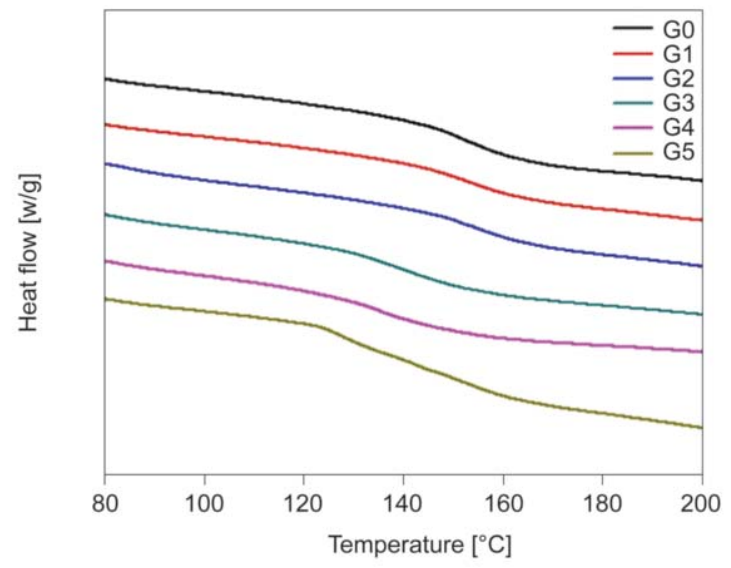

Figure 4. DSC thermograms of the binary composites vs glass mat content

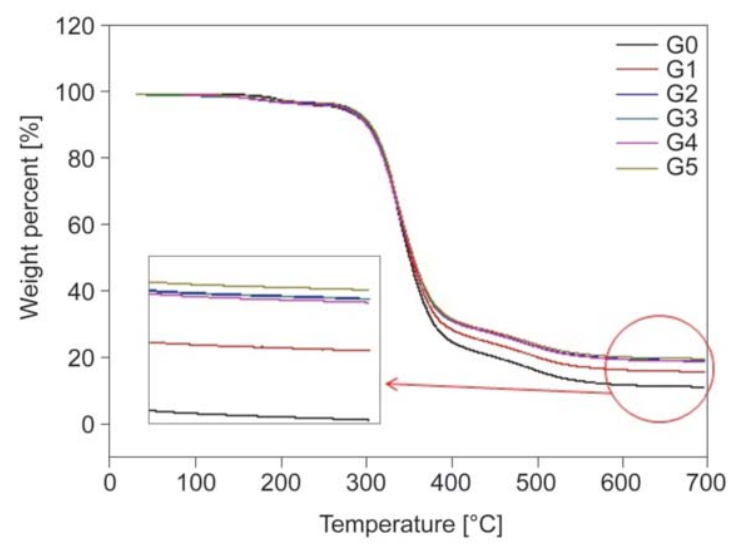

Figure 5. TGA thermograms of the binary composites vs glass mat content

glass mat (G2). With the addition of glass mats, thermal motions of the polymer chains are restricted to increase the $T_{\mathrm{g}}$. The maximum value of $T_{\mathrm{g}}$ appeared at low glass mat content implies that glass mats are not well dispersed in polymer melts at high contents. The thermal decomposition temperatures of the binary composites again show that maximum $T_{10}(10 \%$ weight loss temperature) and $T_{50}$ are obtained at $2 \%$ glass mat composition (Figure 5). This effect can be explained by a decrease of the diffusion of oxygen and volatile products throughout the glass mats.

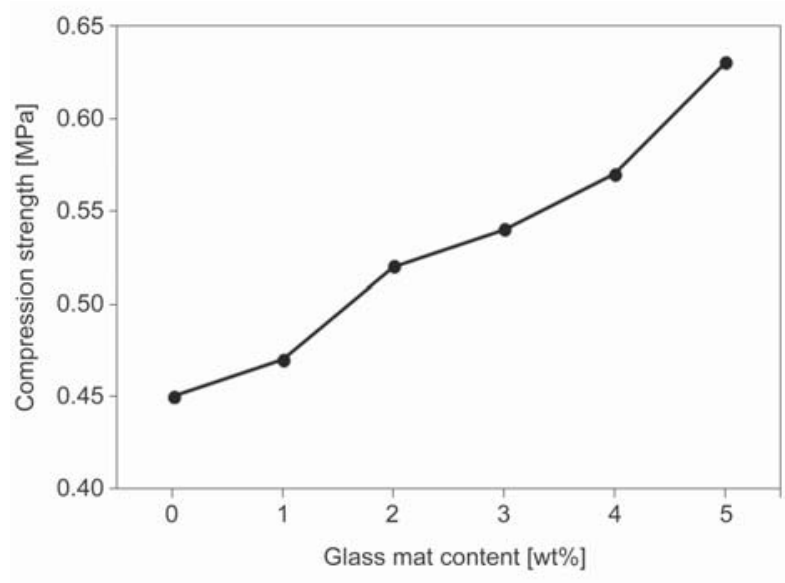

Figure 6. Compression strength of the binary composites vs glass mat content

\subsection{Compression strength}

Compression strength is a key property of rigid foams since foams are typically used under compressed condition. It is seen that the compression strengths of the composites almost linearly increase by a factor of 1.5 as the glass mat content increases from 0 to $5 \%$ (G5) (Table 3 and Figure 6). The linear variation of the strength as compared with the existence of a maximum $T_{\mathrm{g}}$ implies that the compression strength is a bulk property which mainly depends on the overall composition [22]. The compression strength was determined at $10 \%$ strain, where the properties are mostly determined by the bulk composition rather than the orientation or morphology which correspond to the state of large deformation.

\subsection{RPUF/glass mat/silica ternary composites}

Effects of silica incorporation were studied at 2\% glass mat (Table 4). The process times of the foaming process significantly increase with the addition and increasing amount of silica due to the increased mixture viscosity. The suspension viscosity increases linearly at low and rapidly at high filler concentration especially over $2 \%$, indicative of particle aggregations.

Table 4. Reactivity and property of the ternary composites vs silica content

\begin{tabular}{|l|c|r|r|r|r|r|}
\hline & G2 & GS1 & GS2 & GS3 & GS4 & GS5 \\
\hline Cream time $[\mathrm{s}]$ & $30-35$ & 69 & 82 & 91 & 100 & 109 \\
\hline Rise time $[\mathrm{s}]$ & $230-245$ & 311 & 355 & 383 & 415 & 440 \\
\hline Gel time $(\mathrm{s})$ & $480-505$ & 606 & 665 & 705 & 753 & 789 \\
\hline Tack-free time $[\mathrm{s}]$ & $785-820$ & 1003 & 1077 & 1130 & 1192 & 1243 \\
\hline Density $\left[\mathrm{kg} / \mathrm{m}^{3}\right]$ & 126.17 & 130.75 & 133.30 & 136.32 & 141.03 & 146.01 \\
\hline$T_{\mathrm{g}}\left[{ }^{\circ} \mathrm{C}\right]$ & 155.89 & 156.72 & 158.15 & 159.14 & 157.55 & 157.10 \\
\hline$T_{10}\left[{ }^{\circ} \mathrm{C}\right]$ & 303.44 & 304.40 & 305.86 & 308.22 & 306.99 & 305.91 \\
\hline$T_{50}\left[{ }^{\circ} \mathrm{C}\right]$ & 354.42 & 355.14 & 358.37 & 365.52 & 357.58 & 358.54 \\
\hline Compression strength $[\mathrm{MPa}]$ & 0.94 & 1.06 & 1.11 & 1.17 & 1.21 & 1.23 \\
\hline
\end{tabular}


The suspension viscosity is well described by a power law given by Equation (1) [23]:

$\eta_{\mathrm{r}}=1+B \varphi+C \varphi^{2}+\ldots$

where $\eta_{\mathrm{r}}$ is the relative viscosity, $B=2.5$ (Einstein constant), $7.25 \leq C \leq 14.1$. As the particle concentration increases particle-particle interactions become significant.

Density of the ternary composites increases monotonically with the silica content (Table 4).

The $T_{\mathrm{g}}$ and thermal decomposition temperatures of the ternary composites increased with the addition of silica showing a maximum with $3 \%$ silica (Table 4 ). The existence of maximum seems due to the particle aggregation at high contents as noted from the RPUF/ glass mat binary composites. Compression strength of the ternary composites increased to about 1.5 times of the binary composites with 5\% silica (Table 4).

Figure 7 shows the SEM morphology of the cells with their average size and closed cells content in Table 5. It is seen that the foams consist of spherical and polyhedral shape. The closed cells content is slightly decreased from 92.5 (G2) to around 91\% (GS2-GS5) with the addition of silica particles. However, cells size decreased significantly from 208 (G2) to a minimum of $169 \mu \mathrm{m}(\mathrm{G} 3)$ at $3 \%$ silica, beyond which it increased up to 191 (GS5). The decreased cell size implies that silica acts as a nucleating agent though the effect is less pronounced at high content due to the particle aggregation [16]. Decreased cell size gives increased number of cells, which provides more resistance layers to heat transfer to follow.

Heat conduction through the closed cell foams can be approximated by a series model, which is composed of polymer walls and gas cells in series [24, 25]. Conductive heat flux $(q)$ through the composite wall is given by Equation (2):

$q=\frac{\Delta T}{R}$

where $\Delta T$ is the temperature drop across the foam and $R$ is the conduction resistance given by the following Equation (3):

$$
R=\sum_{\mathrm{i}=1}^{\mathrm{n}}\left(\frac{X_{\mathrm{W}, \mathrm{i}}}{k_{\mathrm{W}}}+\frac{X_{\mathrm{G}, \mathrm{i}}}{k_{\mathrm{G}}}\right)
$$

where $X_{\mathrm{W}, \mathrm{i}}$ and $X_{\mathrm{G}, \mathrm{i}}$ are the cell wall thickness and cell dimension, and $n$ is the number of polymer walls, respectively. For uniform cells, wall thickness $\left(X_{\mathrm{W}, \mathrm{i}}\right)$ and cell dimension $\left(X_{\mathrm{G}, \mathrm{i}}\right)$ are constant and Equation (3) becomes Equation (4):

$R=n\left(\frac{X_{\mathrm{W}}}{k_{\mathrm{W}}}+\frac{X_{\mathrm{G}}}{k_{\mathrm{G}}}\right)$

In typical closed cell foam, the polymer walls occupy $3-6 \mathrm{vol} \%$ of the foam [1]. In addition, the conductivity of the polymer is much greater than that of the blowing gas. So, the first term in Equation (4), viz. polymer wall resistance can be neglected to give. Equation (5) shows that the thermal insulation of closed cell foams increase linearly with the number of closed cells, i.e., the effect of insulation increases as the cell size decreases:

$R=n\left(\frac{X_{\mathrm{G}}}{k_{\mathrm{G}}}\right)$

Thermal conductivity $(k)$ which is commonly called as $k$-factor is a most important property of foam for insulation application. Thermal conductivity of the virgin foam increases with the addition of glass mat (G2) due to the high value of $k$ for glass mat, and decreases with the addition of silica up to $3 \%$, where the value is even lower than the virgin foam. However, as the silica content further increases $k$ value again increases (Figure 8). The decrease is mainly due to the decreased cell size providing a large number of cell $(n)$ as analyzed above. However, the increase at high silica contents may imply that wall effect and other heat transfer mechanism such as radiation should be considered, aside from the particle aggregation.

\section{Conclusions}

Rigid polyurethane foam (RPUF)/glass mat composites have been fabricated from glass fiber mat, polymeric MDI and polyol using an environmentally friendly blowing agent.

Table 5. Cells size and closed cells content of the ternary composites

\begin{tabular}{|l|r|r|r|r|r|r|r|}
\hline & \multicolumn{1}{|c|}{ G0 } & G2 & GS1 & GS2 & GS3 & GS4 & GS5 \\
\hline Cells size $[\mu \mathrm{m}]$ & 226.3 & 208.2 & 192.8 & 185.9 & 169.3 & 179.5 & 191.0 \\
\hline Closed cell content $[\%]$ & 93.2 & 92.5 & 91.6 & 91.0 & 90.0 & 90.6 & 91.4 \\
\hline
\end{tabular}




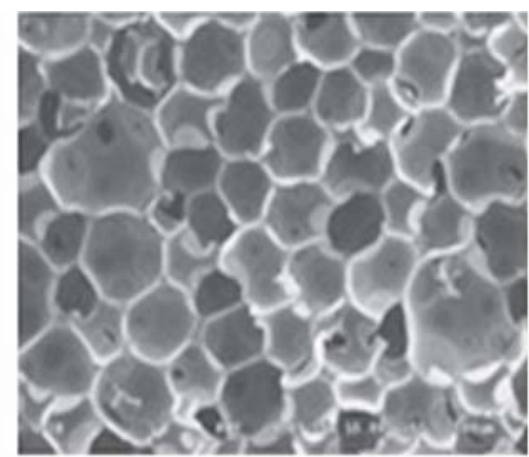

GO

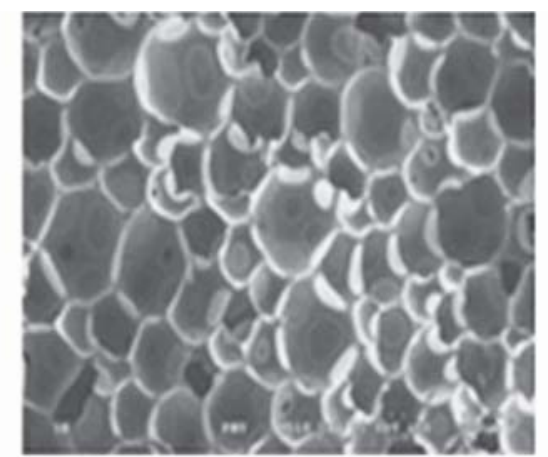

G2

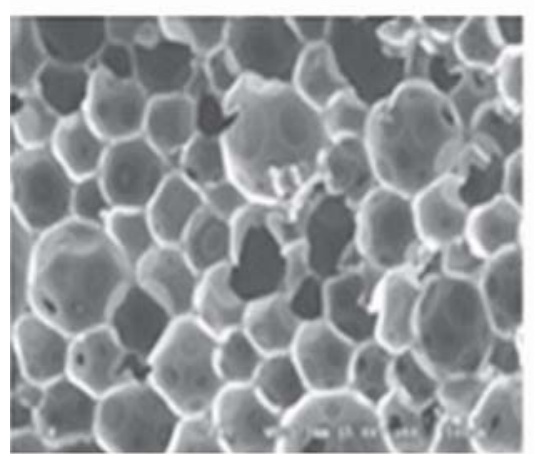

GS1

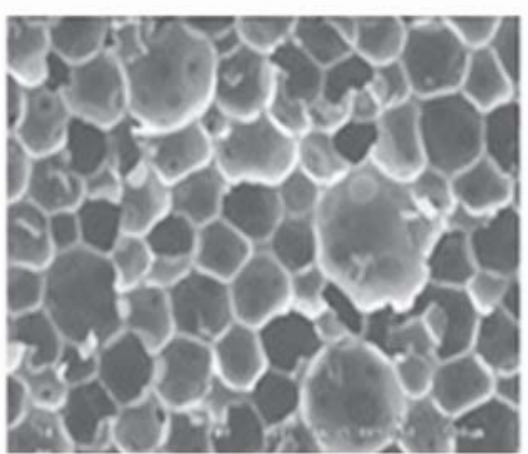

GS2

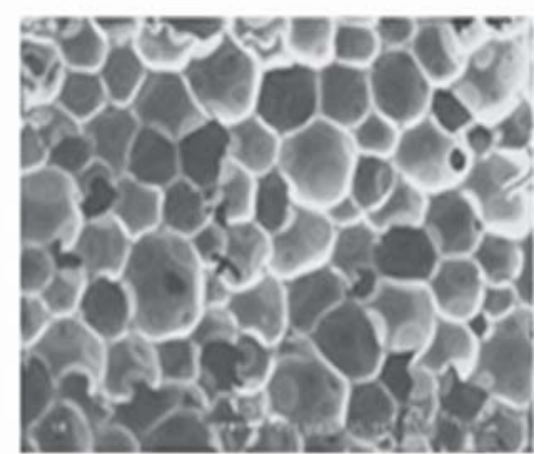

GS3

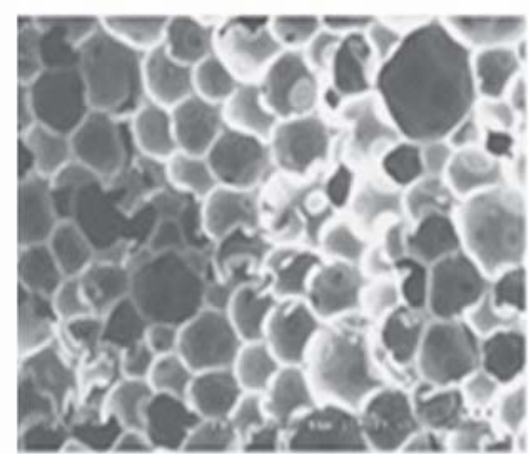

GS4

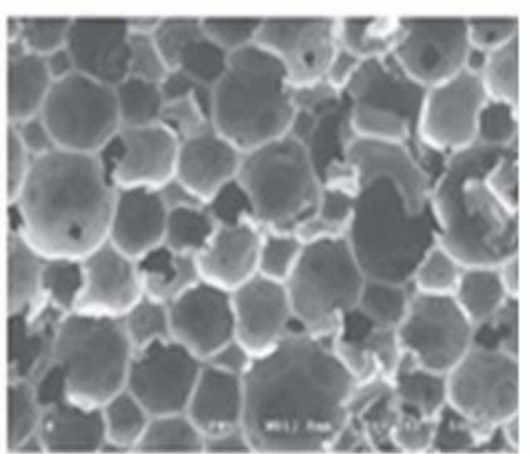

GS5

Figure 7. SEM morphology of the ternary composites

Rise time, gel time and tack-free time increased with the addition and increasing amount of glass mat in-

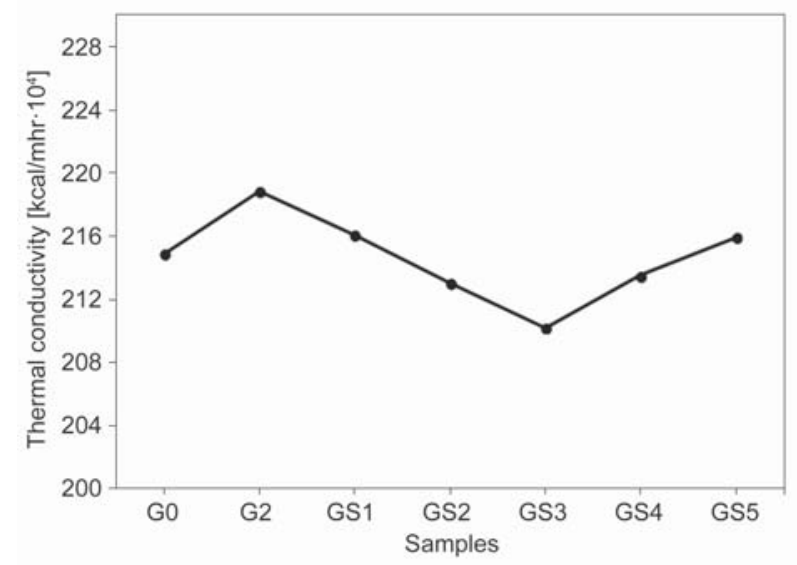

Figure 8. Thermal conductivity of the ternary composites dicating that glass mat interrupts forming and gelling reactions due to the increased mixture viscosity.

Foam density increased as the glass mat content increased due to the larger density of glass mat than the foam.

The $T_{\mathrm{g}}$ and thermal stability of the binary composites increased with the addition of glass mat showing a maximum at $2 \%$. With the addition of glass mat, thermal motion of the polymer chains and diffusion of gas are restricted. The unusual results shown with 3\% glass mat are perhaps due to the poor dispersion of the glass mat at high content.

The compression strengths of the composites almost linearly increased by a factor of 1.5 as the glass mat content increases to $5 \%$. The linear variation of the strength is mainly due to its bulk property. The 
increase was also in accordance with the increased foam density.

RPUF/glass mat/silica ternary composites have been fabricated from silica, glass fiber mat (2\%), PMDI and polyol using an environmentally friendly blowing agent.

The process times of the foaming process significantly increased with the addition and increasing amount of silica due to the increased viscosity.

Density, compression strength of the ternary composites increased with the silica content.

$T_{\mathrm{g}}$ and thermal decomposition temperatures of the ternary composites increased with the addition of silica showing a maximum with $3 \%$ silica. The existence of maximum seems due to the particle aggregation as noted from the RPUF/glass mat binary composites. Cell size, closed cell content decreased with silica showing a minimum at 3\% silica. Decrease of cell size, closed cell content is caused by the nucleating effect of silica and cell opening. The increase in cell size and closed cell content at $4 \%$ reflects poor dispersion of the silica at high silica contents.

The thermal conductivity of the ternary composites decreased linearly with increasing silica content up to $3 \%$ silica mainly due to the decreased cell size and increased number of cell $(n)$. On the other hand, the conductivity upturn at high silica content is interpreted in terms of wall resistance and other heat transfer mechanism, which may become significant at high silica contents.

\section{Acknowledgements}

The research has been supported by Global Core Research Center for Ships and Offshore Plants and National Research Foundation through the Basic Research Program 2015.

\section{References}

[1] Szycher M.: Szycher's handbook of polyurethanes. CRC Press, New York (2012).

[2] You M., Zhang X. X., Wang J. P., Wang X. C.: Polyurethane foam containing microencapsulated phasechange materials with styrene-divinybenzene co-polymer shells. Journal of Materials Science, 44, 3141-3147 (2009). https://doi.org/10.1007/s10853-009-3418-7

[3] Tavares L. B., Boas C. V., Schleder G. R., Nacas A. M., Rosa D. S., Santos D. J.: Bio-based polyurethane prepared from Kraft lignin and modified castor oil. Express Polymer Letters, 10, 927-940 (2016).

https://doi.org/10.3144/expresspolymlett.2016.86
[4] Sonnenschein M. F.: Polyurethane: Science, technology, market, and trend. Wiley, New York (2015).

[5] Global polyurethanes market report 2015-2020, Business Wire, Dublin (2016).

[6] Kim B. K.: Cleaner, greener routes for polyurethanes. Express Polymer Letters, 10, 873 (2016).

https://doi.org/10.3144/expresspolymlett.2016.81

[7] Cao X., Lee L. J., Widya T. C., Macosko C.: Polyurethane/clay nanocomposites foams: Processing, structure and properties. Polymer, 46, 775-783 (2005).

https://doi.org/10.1016/j.polymer.2004.11.028

[8] Mondal P., Khakhar D. V.: Regulation of cell structure in water blown rigid polyurethane foam. Macromolecular Symposia, 216, 241-254 (2004).

https://doi.org/10.1002/masy.200451223

[9] Seo W. J., Jung H. C., Hyun J. C., Kim W. N., Lee Y-B., Choe K. H., Kim S-B.: Mechanical, morphological, and thermal properties of rigid polyurethane foams blown by distilled water. Journal of Applied Polymer Science, 90, 12-21 (2005).

https://doi.org/10.1002/app.12238

[10] Antolini B., Bianchi F., Bottazzi M., Careri M.: Development and validation of novel DH-GC-ITMS methods for the determination of freon F-141b in formulated polyol and rigid polyurethane foam. Chromatographia, 60, 323-327 (2004). https://doi.org/10.1365/s10337-004-0393-7

[11] Kim S. H., Park H. C., Jeong H. M., Kim B. K.: Glass fiber reinforced rigid polyurethane foams. Journal of Materials Science, 45, 2675-2680 (2010).

https://doi.org/10.1007/s10853-010-4248-3

[12] Wilberforce S., Hashemi S.: Effect of fibre concentration, strain rate and weldline on mechanical properties of injection-moulded short glass fibre reinforced thermoplastic polyurethane. Journal of Materials Science, 44, 1333-1343 (2009). https://doi.org/10.1007/s10853-008-3233-6

[13] Kang S. M., Kwon S. H., Park J. H., Kim B. K.: Carbon nanotube reinforced shape memory polyurethane foam. Polymer Bulletin, 70, 885-893 (2013). https://doi.org/10.1007/s00289-013-0905-4

[14] Xu Z., Tang X., Gu A., Fang Z.: Novel preparation and mechanical properties of rigid polyurethane foam/organoclay nanocomposites. Journal of Applied Polymer Science, 106, 439-447 (2007).

https://doi.org/10.1002/app.26497

[15] Harikrishnana G., Umasankar Patro T., Khakhar D. V.: Reticulated vitreous carbon from polyurethane foamclay composites. Carbon, 45, 531-535 (2007). https://doi.org/10.1016/j.carbon.2006.10.019

[16] Kang S. M., Kim M. J., Kwon S. H., Park H., Jeong H. M., Kim B. K.: Polyurethane foam/silica chemical hybrids for shape memory effects. Journal of Materials Science, 27, 2837-2843 (2012). https://doi.org/10.1557/jmr.2012.334 
[17] Karger-Kocsis J., Harmia T., Czigány T.: Comparison of the fracture and failure behavior of polypropylene composites reinforced by long glass fibers and by glass mats. Composites Science and Technology, 54, 287298 (1995).

https://doi.org/10.1016/0266-3538(95)00068-2

[18] Seo W. J., Park J. H., Sung Y. T., Hwang D. H., Kim W. N., Lee H. S.: Properties of water-blown rigid polyurethane foams with reactivity of raw materials. Journal of Applied Polymer Science, 93, 2334-2342 (2004). https://doi.org/10.1002/app.20717

[19] Singh H., Sharma T. P., Jain A. K.: Reactivity of the raw materials and their effects on the structure and properties of rigid polyurethane foams. Journal of Applied Polymer Science, 106, 1014-1023 (2007).

https://doi.org/10.1002/app.26525

[20] Vashisht U., Kausha J.: Synthesis and kinetic studies of rigid polyurethane foam based on modified castor oil. Chitkara Chemistry Review, 1, 71-82 (2013).

https://doi.org/10.15415/ccr.2013.12012
[21] Song B., Lu W-Y., Syn C. J., Chen W.: The effects of strain rate, density, and temperature on the mechanical properties of polymethylene diisocyanate (PMDI)-based rigid polyurethane foams during compression. Journal of Materials Science, 44, 351-357 (2009). https://doi.org/10.1007/s10853-008-3105-0

[22] Gent A. N., Ellul M. D., Finney R. H., Hamed G. R., Hertz D. L., James F. O., Lake G. D., Miller T. S., Campion R. P.: Enginering with rubber. Hanser, Munich (2016).

[23] Mueller S., Llewellin E. W., Mader H. M.: The rheology of suspensions of solid particles. Proceedings Royal Society A, 466, 161-179 (2010).

https://doi.org/10.1098/rspa.2009.0445

[24] Bird R. B., Stewart W. E., Lightfoot E. N.: Transport phenomena. Wiley, New York (2006).

[25] Wang M., Pan N.: Modeling and prediction of the effective thermal conductivity of random open-cell porous foams. International Journal of Heat and Mass Transfer, 51, 1325-1331 (2008). https://doi.org/10.1016/j.ijheatmasstransfer.2007.11.031 